\title{
Utility of Cytological Grading in Proliferative Epithelial Lesions of Breast
}

\author{
Sai Chandana Gali ${ }^{1 *}$, Udaya Kumar $\mathbf{M}^{2}$, Nirmala $M \mathrm{~J}^{2}$, Prashanth $\mathrm{R}^{3}$ and Ramaswamy $\mathrm{A} \mathrm{S}^{2}$ \\ ${ }^{1}$ Department of Pathology, SVIMS, Tirupathi, Chittoor, Andhra pradesh, India \\ ${ }^{2}$ Department of pathology, PESIMSR, Kuppam, Chittoor, Andhra Pradesh, India. \\ ${ }^{3}$ Apollo Diagnostics Regional Laboratory, AVS compound, 80 feet road, Koramangala 4th block, Bengaluru, India
}

\section{ABSTRACT}

Background: Breast carcinoma is the second most common malignancy in women. Fine needle aspiration cytology of breast is rapid, reliable and safe diagnostic tool to distinguish between neoplastic and non neoplastic lesions. Cytological grading of the smears can provide valuable prognostic information.

Aims and Objectives: To study the utility of Masood cytological grading system and to compare it against a new proposed cytological grading system in proliferative epithelial lesions of breast.

Methods: The Papanicolaou (PAP) stained Fine Needle Aspiration Cytology (FNAC) smears of proliferative breast lesions were cytologically graded by the Masood cytological grading system and by the newly proposed grading system by two observers independently. Results were correlated with the histopathological diagnosis.

Result: In the study period of 2 years, 54 proliferative epithelial lesions were studied of which 47 were proliferative breast disease without atypia and seven proliferative breast diseases with atypia. 42/54 cases in newly proposed system showed concordance with existing Masood grading system. p-value is $0.000(<0.005)$ which is significant. Sensitivity, specificity, positive predictive value and negative predictive value for newly proposed grading system were $88.67 \%, 100 \%, 100 \%$ and $85.71 \%$ respectively.

Conclusion: A simple slide based scoring system of epithelial lesions of breast is a useful tool in the prognostication and prediction of behavior of proliferative epithelial lesions.

Keywords: Breast Carcinoma, Fine Needle Aspiration Cytology, Cytological Grading

\section{Introduction}

Breast cancer is the leading cause of morbidity and mortality. ${ }^{1}$ In India, breast cancer is the second most common malignancy in women, next to cervical cancer. ${ }^{2}$ Increase in cases of breast cancers are related to late marriage, birth of child in the later age, shorter period of breast feeding and nulliparity or low parity. ${ }^{1}$ By $2020,70 \%$ of the world's cancer cases will be in poor countries, with a fifth in India. Breast cancer is set to overtake cervical cancer as the most common type of cancer among all women in India. ${ }^{3}$

Clinically, the diseases of breast present with lump in breast or nipple discharge. ${ }^{1}$ Most cases of breast lumps are benign, but sometimes, it is difficult to determine whether a suspicious lump is benign or malignant, simply by doing a clinical examination. In these circumstances, as a widely accepted and established outdoor patient procedure, Fine Needle Aspiration Cytology (FNAC) plays an important role in determining the nature of the lump. Accurate diagnosis of breast cancer is made in $99 \%$ of cases by the combination of clinical examination, mammography and simple, outpatient department procedure, FNAC. ${ }^{4}$

FNAC is a simple and safe method which yields high diagnostic results. The procedure is considered very cost effective by being less invasive, rapid and as sensitive as biopsy. ${ }^{3}$

Core-needle biopsy (CNB) is increasingly replacing FNAC in many centers in developed countries and this is mainly attributed to the inability of FNAC to distinguish carcinoma in situ from invasive carcinoma. ${ }^{5}$ Moreover, for resource poor countries, FNA in comparison to core needle biopsy, is cheaper, less invasive, can sample different areas of the lesion in the same sitting at no additional expenditure and usually yield good results the same day. ${ }^{4}$

Prognosis of breast carcinoma depends on various parameters, such as tumor type, histological grading (HG), hormone receptor status, DNA ploidy, cell proliferation markers and expression of different oncogenes. ${ }^{6} \mathrm{HG}$ of breast carcinoma using the Elston Ellis modification of Scarff Bloom Richardson (SBR) grading system is a widely 
accepted tumor grading system and has been found to have good prognostic correlation. Of the different cytological grading (CG) methods corresponding to Elston Ellis modified SBR HG, the method described by Robinson et al. is found to be useful in grading breast carcinoma in fine needle aspiration (FNA). ${ }^{6}$ Numerous two-tier and three-tier systems have been proposed for the cytological grading of breast tumors, but no single system is currently adapted for use in the routine evaluation of cytological aspirates of breast carcinoma. ${ }^{2}$

Masood et al, developed a cytological grading system to delineate breast lesions into benign, premalignant and malignant based on the cellular arrangement (relationship of cells to one another in a sheet of ductal epithelial cells), the degree of cellular pleomorphism (the variation in cell size of the ductal epithelial cells), anisonucleosis, the presence of myoepithelial cells, nucleoli and the status of chromatin pattern like clumping of chromatin. It is graded in to four categories viz., non proliferative breast disease (NPBD), proliferative breast disease (PBD) without atypia, proliferative breast disease with atypia, carcinoma in-situ $\&$ invasive carcinoma. ${ }^{7}$

Proliferative breast disease is a morphologic continuum that includes hyperplasia without atypia, hyperplasia with atypia, and carcinoma in-situ. The cytologic categorization of these lesions is valuable in identifying women at variably increased risk for underlying invasive breastcancer. ${ }^{8}($ Table-1)

For breast malignancy three-tier system have been proposed by Robinson, Taniguchi, Mouriquand, Howell, Kahn and Fisher. ${ }^{10}$ In the present study, parameters from these cytological grading systems are combined to form a unified grading system. They are compared with the existing Masood grading system

\section{Materials and Methods}

FNAC samples from patients having palpable breast lumps displaying features of proliferative epithelial breast lesion are the basis of study. The PAP stained smears of these lesions are cytologically graded by the Masood cytological grading system (Table No.2) The same smears are also graded cytologically by the following newly proposed grading system (Table No.3) Both these gradings are done by two observers independently. Results of cytological grading are correlated with the histopathological specimens whereever available.

\section{Result}

The patients included in the study were 54, all were females with age range of 17-61 years. The maximum number of cases was in the age group of 21-40 years. In 26/54 cases, lesion is located in the left breast, predominantly in upper outer quadrant. Most of the patients are presented with lump in the breast. Present study includes only proliferative lesions of breast without atypia (47 cases) and with atypia (7 cases) graded by Masood cytology grading system. Among 47 cases of PBD without atypia, 36 cases $(66 \%)$ are diagnosed as fibroadenoma, $9(16 \%)$ cases as benign breast disease, 2 cases $(4 \%)$ as phyllodes tumor. Cases graded with Masood grading system are correlated with Nottingham histological grading system (Table-4), which showed $\mathrm{p}$ value $<0.05$ (significant), sensitivity - $88.67 \%$, specificity - $100 \%$, positive predictive value $100 \%$ and negative predictive value $-85.71 \%$. The same proliferative lesions are again graded by newly proposed cytology grading system, 10 cases as benign, 37 cases as PBD without atypia, 5 cases as PBD with atypia and 2 cases as malignant. On correlation with Nottingham grading system (Table-5) showed p value $<0.05$, sensitivity - $88.67 \%$, specificity - $100 \%$, positive predictive value $100 \%$ and negative predictive value $-85.71 \%$. Cases graded on Masood are correlated with Newly proposed system (Table-6), of which $52(96.3 \%)$ cases out of 54 cases on Masood correlated with the newly proposed system. Two cases $(3.7 \%)$ graded as PBD with atypia on Masood system are graded as malignant on Newly proposed system.

Interobserver variability is calculated separately for Masood grading system and newly proposed grading system. Cronbach alpha for Masood scores - 0.978, Cronbach alpha for newly proposed scores - 0.955 (Reliability is good if the Cronbach alpha is $>0.7$ )

\section{Discussion}

Non-cancerous diseases of the breast have assumed increasing importance in recent times because of the public awareness of breast cancer. The vast majority of the lesions that occur in the breast are benign. ${ }^{11}$ The cytologic categorization of these lesions are valuable in identifying women at variably increased risk for underlying invasive breast cancer.

Proliferative breast ductal lesions short of invasive cancer have been broadly classified into those with: (1) No increased risk (mild hyperplasia), (2) Slightly increased risk (moderate or florid hyperplasia), (3) Moderately increased risk (atypical ductal hyperplasia), and (4) High risk (ductal carcinoma insitu [DCIS]). ${ }^{12}$

Present study included the FNAC material from 54 breast cases in which the cytomorphological features are studied in detail.

Majority of patients age ranged from 17 to 61 years with majority in the $21-40$ years, which correlated with other 
Table 1: Epithelial breast lesions and risk of developing invasive carcinoma ${ }^{9}$

\begin{tabular}{|l|c|}
\hline PATHOLOGIC LESION & RELATIVE RISK \\
\hline Nonproliferative Breast Changes: & $13 \%)$ \\
Duct-ectasia & \\
Cysts & \\
Apocrinechange & 1.5 to $2(5 \%-7 \%)$ \\
Mildhyperplasia & \\
Adenosis & \\
\hline Proliferative Disease Without Atypia: & \\
Moderate or florid hyperplasia & \\
Sclerosing-adenosis & \\
Papilloma & \\
Complex sclerosing lesion (radial scar) & \\
Fibroadenoma with complex features & \\
\hline Proliferative Disease with Atypia: & \\
Atypical ductal hyperplasia (ADH) & \\
Atypical lobular hyperplasia (ALH) & \\
\hline Carcinoma in Situ: & $17 \%)$ \\
Lobular carcinoma in situ (LCIS) & \\
Ductal carcinoma in situ (DCIS) & \\
\hline
\end{tabular}

Table 2: Masood grading system

\begin{tabular}{|c|c|c|c|c|}
\hline $\begin{array}{c}\text { Masoods } \\
\text { cytology } \\
\text { grading }\end{array}$ & $\mathbf{1}$ & $\mathbf{2}$ & $\mathbf{3}$ \\
\hline $\begin{array}{c}\text { Cellular } \\
\text { arrangement }\end{array}$ & $\begin{array}{c}\text { Monolayered } \\
\text { sheets } \\
\text { Cellular } \\
\text { pleomorphism }\end{array}$ & $\begin{array}{c}\text { Nuclear } \\
\text { overlapping }\end{array}$ & Clustering & $\begin{array}{c}\text { Loss of } \\
\text { cohesion }\end{array}$ \\
\hline $\begin{array}{c}\text { Myoepithelial } \\
\text { cells }\end{array}$ & Absent & Mild & Moderate & Conspicuous \\
\hline Anisonucleosis & Absent & Moderate & Few & Conspicuous \\
\hline $\begin{array}{c}\text { Nucleoli } \\
\text { Chromatin } \\
\text { clumping }\end{array}$ & Absent & $\begin{array}{c}\text { Micro } \\
\text { nucleoli }\end{array}$ & $\begin{array}{c}\text { Micro/rare } \\
\text { macro } \\
\text { nucleoli }\end{array}$ & $\begin{array}{c}\text { Predominant } \\
\text { nucro } \\
\text { nucleoli }\end{array}$ \\
\hline
\end{tabular}

Masood grading score:

\begin{tabular}{|c|c|}
\hline $6-10$ & Non proliferative breast disease \\
\hline $11-14$ & Proliferative breast disease without atypia \\
\hline $15-18$ & Proliferative breast disease with atypia \\
\hline $19-24$ & Ca insitu \& invasive carcinoma \\
\hline
\end{tabular}

Table 3: Newly proposed grading system.

\begin{tabular}{|c|c|c|c|}
\hline $\begin{array}{c}\text { NEWLY } \\
\text { PROPOSED } \\
\text { GRADING }\end{array}$ & 1 & 2 & 3 \\
\hline $\begin{array}{c}\text { Cell } \\
\text { arrangement }\end{array}$ & $\begin{array}{c}\text { Monolayered } \\
\text { sheets }\end{array}$ & $\begin{array}{l}\text { Singles \& } \\
\text { clusters }\end{array}$ & Only singles \\
\hline Cell size & $1-2 x R B C$ & $3-4 \times R B C$ & $\begin{array}{c}\text { More than } \\
5 \mathrm{Xrbc}\end{array}$ \\
\hline $\begin{array}{c}\text { Cell } \\
\text { pleomorphism }\end{array}$ & Absent & Mild & Highly \\
\hline
\end{tabular}




\begin{tabular}{|c|c|c|c|}
\hline $\begin{array}{c}\text { NEWLY } \\
\text { PROPOSED } \\
\text { GRADING }\end{array}$ & $\mathbf{1}$ & $\mathbf{2}$ & $\mathbf{3}$ \\
\hline Nuclear margin & Smooth & Irregular & Buds \& clefts \\
\hline Nucleoli & Absent & Inconspicuous & Prominent \\
\hline Chromatin & Fine & Rranular & Rlumping \\
\hline Mitosis & Absent & $\begin{array}{c}\text { Cells with few } \\
\text { clusters }\end{array}$ & Absent \\
\hline $\begin{array}{c}\text { Myoepithelial } \\
\text { cells }\end{array}$ & $\begin{array}{c}\text { Cells with } \\
\text { most clusters } \\
\text { cells }\end{array}$ \\
\hline Necrosis & Absent & Few & Marked \\
\hline $\begin{array}{c}\text { Bare bipolar } \\
\text { nuclei }\end{array}$ & Many & Few & Absent \\
\hline
\end{tabular}

Scoring:

\begin{tabular}{|c|c|}
\hline $10-13$ & Benign \\
\hline $14-16$ & Proliferative breast disease without atypia \\
\hline $17-19$ & Proliferative breast disease with atypia \\
\hline $20-30$ & Malignant \\
\hline
\end{tabular}

Table 4: Correlation of Masood cytological and histological typing:

\begin{tabular}{|c|c|c|c|c|c|c|c|}
\hline \multirow{2}{*}{$\begin{array}{c}\text { Cytology } \\
\text { diagnosis }\end{array}$} & \multicolumn{6}{|c|}{ Histopathological diagnosis } & \multirow[t]{2}{*}{ Total } \\
\hline & FA & $\begin{array}{c}\text { Fibroadenosis/ } \\
\text { FCD }\end{array}$ & BBD & $\begin{array}{l}\text { Phyllode } \\
\text { tumor }\end{array}$ & $\begin{array}{c}\text { Ductal } \\
\text { hyperplasia }\end{array}$ & Malignant & \\
\hline FA & $33(86.8 \%)$ & $1(25 \%)$ & & $2(50 \%)$ & & & 36 \\
\hline BBD & $5(13.2 \%)$ & $3(75 \%)$ & & & $1(100 \%)$ & & 9 \\
\hline Phyllodes tumor & & & & $2(50 \%)$ & & & 2 \\
\hline PBD with atypia & & & $1(100 \%)$ & & & $6(100 \%)$ & 7 \\
\hline Total & 38 & 4 & 1 & 4 & 1 & 6 & 54 \\
\hline
\end{tabular}

\section{CHISQUARE TEST}

\begin{tabular}{|l|l|l|l|}
\hline & Value & Df & P \\
\hline Pearson Chi-Square & 45.329 & 2 & .000 \\
\hline
\end{tabular}

Sensitivity: $88.67 \%$

Specificity: $100 \%$

Positive-predictivevalue: $100 \%$

Negative predictive value: $85.71 \%$

Table 5: Correlation of newly proposed system and histological typing

\begin{tabular}{|c|c|c|c|c|c|c|c|}
\hline & FA & $\begin{array}{l}\text { Fibroadenosis/ } \\
\text { FCD }\end{array}$ & BBD & $\begin{array}{l}\text { Phyllode } \\
\text { tumor }\end{array}$ & $\begin{array}{c}\text { Ductal } \\
\text { hyperplasia }\end{array}$ & Malignant & \\
\hline Benign & $9(23.7 \%)$ & $1(25 \%)$ & & & & & 10 \\
\hline $\begin{array}{l}\text { PBD without } \\
\text { atypia }\end{array}$ & $29(76.3 \%)$ & $3(75 \%)$ & & $4(100 \%)$ & $1(100 \%)$ & & 37 \\
\hline $\begin{array}{l}\text { PBD with } \\
\text { atypia }\end{array}$ & & & $1(100 \%)$ & & & $4(66.6 \%)$ & 5 \\
\hline Malignant & & & & & & $2(33.4 \%)$ & 2 \\
\hline Total & 38 & 4 & 1 & 4 & 1 & 6 & 54 \\
\hline
\end{tabular}




\section{CHI SQUARE TEST}

\begin{tabular}{|c|c|c|c|}
\hline & Value & Df & P \\
\hline Pearson Chi-Square & 47.092 & 6 & .000 \\
\hline
\end{tabular}

Sensitivity: $88.67 \%$

Specificity: $100 \%$

Positive-predictivevalue: $100 \%$

Negative predictive value: $85.71 \%$

Table 6: Correlation of Masood cytological typing with Newly proposed grading system:

\begin{tabular}{|c|c|c|c|c|c|}
\hline \multirow{2}{*}{ Masood } & \multicolumn{4}{|c|}{ Newly proposed grading system } & \multirow{2}{*}{ Total } \\
\hline & Benign & PBD without atypia & PBD with atypia & Malignant & \\
\hline $\mathrm{FA}$ & 9 & 27 & & & 36 \\
\hline BBD & 1 & 8 & & & 9 \\
\hline Phyllodes tumor & & 2 & & & 2 \\
\hline PBD with atypia & & & 5 & 2 & 7 \\
\hline Total & 10 & 37 & 5 & 2 & 54 \\
\hline
\end{tabular}

CHI SQUARE TEST

\begin{tabular}{|c|c|c|c|}
\hline & Value & Df & P \\
\hline Pearson Chi-Square & 54.000 & 3 & .000 \\
\hline
\end{tabular}

Table 7: Comparison of statistics with other studies.

\begin{tabular}{|c|c|c|c|c|}
\hline Study & Senstivity & Specificity & $\begin{array}{c}\text { Positive } \\
\text { predictive } \\
\text { value }\end{array}$ & $\begin{array}{c}\text { Negative } \\
\text { predictive } \\
\text { value }\end{array}$ \\
\hline Chooski et al ${ }^{1}$ & $98.08 \%$ & $98.86 \%$ & $99.35 \%$ & $96.66 \%$ \\
\hline Jindal et al ${ }^{26}$ & $96.42 \%$ & $100 \%$ & $100 \%$ & $93.4 \%$ \\
\hline Choi et al ${ }^{27}$ & $77.7 \%$ & $99.2 \%$ & $98.4 \%$ & $88 \%$ \\
\hline Present study & $88.67 \%$ & $100 \%$ & $100 \%$ & $85.71 \%$ \\
\hline
\end{tabular}

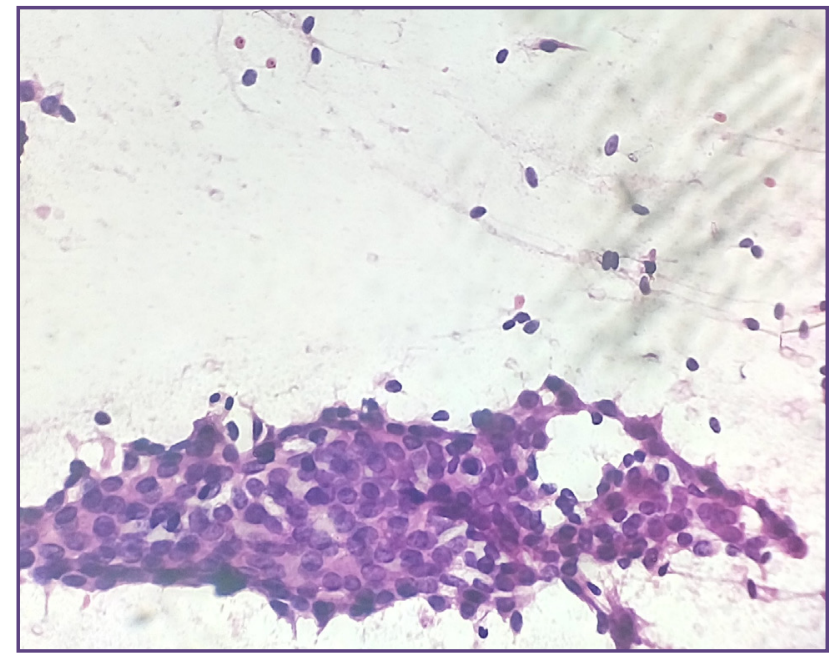

Fig. 1: Microphotograph illustrating epithelial cells in clusters and bare bipolar nuclei (100x H\&E stain).

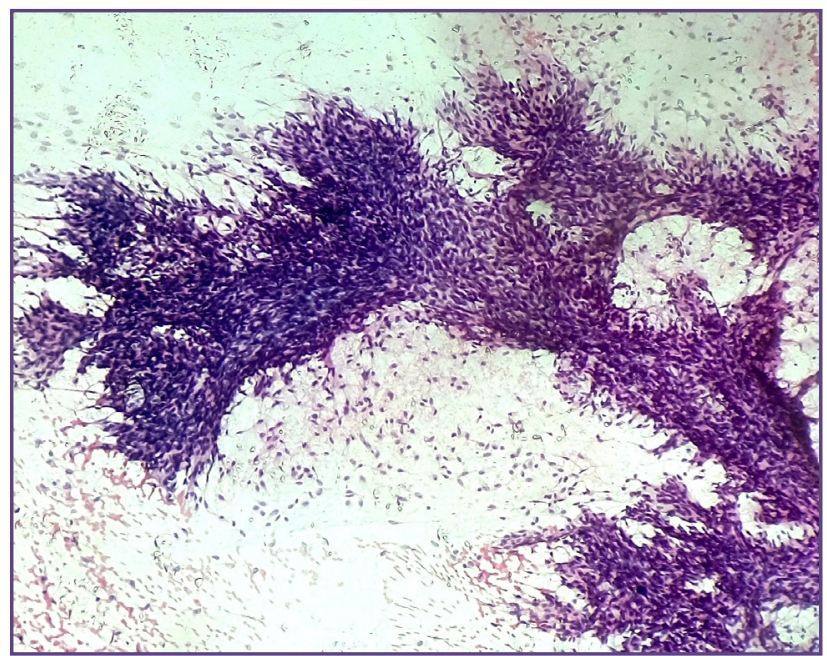

Fig. 2: Microphotograph illustrating phyllode tumor with Stromal hypercellularity (100X H\&E stain). 


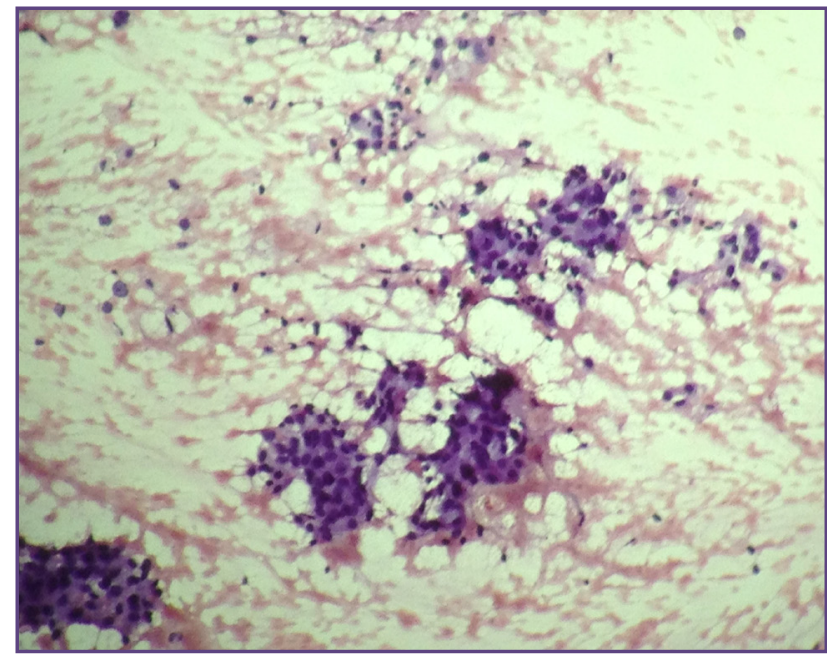

Fig. 3: Microphotograph illustrating epithelial cells arranged in singles and clusters scored three in Masood system and two in new system (100xH\&E stain).

studies Mital chooski et $\mathrm{al}^{1}$, Prem singh et $\mathrm{al}^{13}$. Slight preponderance of breast cases in the left breast which is correlated with previous studies, Muddegowda et $\mathrm{al}^{5}$, Prem singh et $\mathrm{al}^{13}$. Majority of cases in our study are located in upper and outer quadrant similar to Prem singh et $\mathrm{al}^{13}$, Pinki Pandey et $\mathrm{al}^{14}$. Present study included smears of proliferative breast disease without atypia of 47 cases and proliferative breast disease with atypia of seven cases on Masood grading system.

\section{Proliferative Breast Disease Without Atypia}

In the present study 47 / 54 cases are proliferative breast lesion without atypia. Of these 36 cases are fibroadenoma, nine cases of benign proliferative breast disease, two are diagnosed as benign phyllodes tumor. Fibroadenoma is the most common benign tumor observed in grade II lesions. The most common benign lesion in the study done by Mital chooski et al is fibroadenoma of $77.72 \% .^{1}$ The aspirates are moderate to highly cellular and majority of the aspirates showed classical features of fibroadenoma - branching antler horn clusters, bare nuclei and stromal fragments. A background of bare nuclei is an important diagnostic feature of fibroadenoma. ${ }^{15,16}$ This is seen in most of the cases except in four cases which had scanty bare nuclei. In these four cases, the diagnosis is supported by the antler horn clusters composed of ductal epithelial cells and myoepithelial cells. This pattern reflects the configuration of ducts as observed on histological sections. ${ }^{17}$ Diagnosis of low grade phyllodes tumor and its distinction from fibroadenoma on FNAC becomes difficult due to overlapping features between the two lesions. ${ }^{18}$

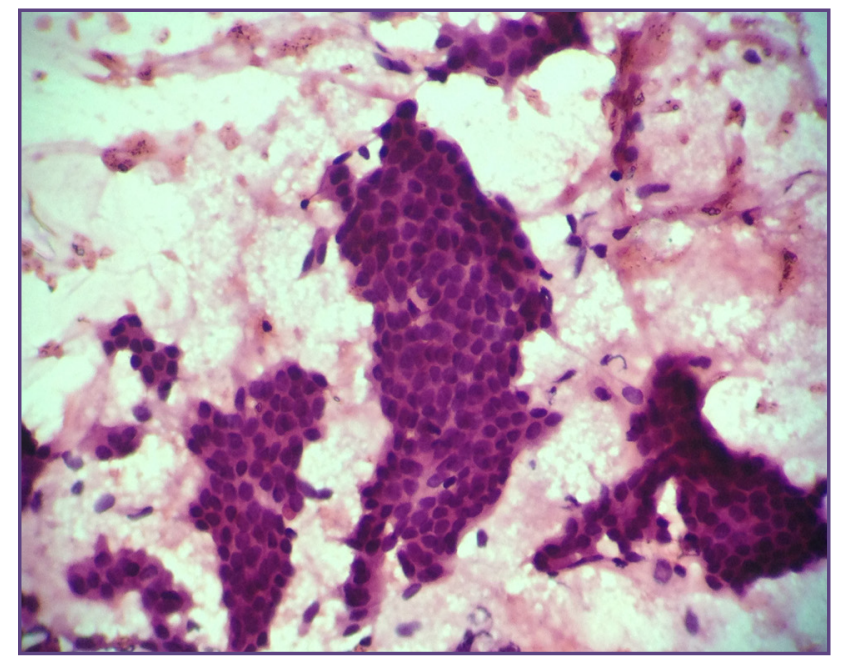

Fig. 4: Microphotograph illustrating epithelial cells with nuclear overlapping scored two in Masood system and scored one in new system (100x H\&E stain).

Phyllodes tumors are distinguished from fibroadenomas on the basis of high cellularity, increased mitotic rate, nuclear pleomorphism, stromal overgrowth, and infiltrative borders. Low grade lesions resemble fibroadenomas but are more cellular and are mitotically active. ${ }^{9}$ Bandyopadyay et al did a study in 2010 comparing cytological characteristics between phyllodes tumour and fibroadenomas in 25 cases. Study showed size, cellularity of stromal fragments and the proportion of spindle cells in the background are important features in the differentiation. ${ }^{18}$ In the present study two cases of phyllodes tumor, on cytology showed moderate cellularity in monolayered sheets with less number of stromal fragments and occasional mitotic figures, hence diagnosed as fibroadenoma on cytology. Histopathological changes of fibroadenosis include fibrosis, adenosis, microcysts, and epithelial hyperplasia. ${ }^{19}$ Of these fibrosis and microcysts less seen on cytology with predominant component of epithelial cells arranged in monolayered sheets which made to diagnose as fibroadenoma.

Nine cases are diagnosed at cytology as benign proliferative breast disease. These cases presented with ill-defined to well formed masses and the smears are poorly to moderately cellular showing few benign clusters of epithelial cells and myoepithelial cells. Five cases in addition showed an antler horn pattern and bare nuclei but are not as abundant as in fibroadenoma. They are absent in the remaining cases. Few cyst macrophages are seen in some cases. Thus these cases had some of the features of either FA or FCD but not all of them. Therefore, a diagnosis of benign proliferative breast disease is given on cytology.

Two cases of benign phyllodes tumor are reported at cytology. Smears showed moderate cellularity with sheets 
of spindle cells and few ductal cells in the hemorrhagic background. Criteria for the diagnosis of benign phyllodes tumor include at least two large stromal fragments, hypercellular fragments and moderate to large number of dissociated stromal cells. ${ }^{18}$

\section{Proliferative Breast Disease with Atypia}

A diagnosis of PBD with atypia at cytology is given on seven cases. Patients are aged between $36-61$ years. In one patient lump is seen in all the quadrants. Two cases showed enlarged axillary lymph nodes. Smears from all these patients showed cohesive clusters of ductal epithelial cells with few bare nuclei and stromal fragments in the background. Few clusters showed atypia in the form of mild to moderate nuclear pleomorphism with prominent nucleoli. Therefore, a cytological diagnosis of PBD with atypia is given. The smear of one patient in addition showed sheets of inflammatory cells composed of lymphocytes, plasma cells and few neutrophills. On histopathological examination of the same case, there is no evidence of atypia or malignancy in several sections studied. Atypia seen on cytology may be accompaniment of reactive changes due to inflammation. ${ }^{15}$ Proliferative breast lesion with atypia is clinically significant because it is associated with a significantly increased likelihood of malignancy compared with proliferative breast lesion without atypia. ${ }^{20} \mathrm{~A}$ study done on clinical utility of the subcategory proliferative breast lesion with atypia by Chengquan Zhao. In this study among 52 proliferative breast lesions with atypia diagnosed by FNA cytology, 19 (36.5\%) cases diagnosed as malignant on histology. ${ }^{20}$

\section{Comparison of Masood Grading System with Histopathology}

Of 36 cytological cases of fibroadenoma, histopathological examination confirmed 33 cases as fibroadenoma. Two are diagnosed as benign phyllodes. One case is diagnosed as fibroadenosis. Fibroadenoma cases showed both intracanalicular and pericanalicular pattern on histopathology. One case amongst those diagnosed as fibroadenoma on histopathology is a giant fibroadenoma. The giant fibroadenoma (juvenile cellular fibroadenoma) is an uncommon variant (4\%) of fibroadenoma characterized by rapid growth. The size of the lesion is usually more than $5 \mathrm{~cm}$ but is encapsulated and benign. The underlying mass may cause a major distortion to the breast contour. ${ }^{21}$ According to Stanford School of Medicine, juvenile fibroadenoma of breast is defined as circumscribed, often large, breast mass occurring in adolescent females with stromal and epithelial hypercellularity but lacking leaf like growth pattern of phyllodes tumors. ${ }^{22}$ Sections of phyllodes tumor showed stromal overgrowth and benign glandular elements as an integral component. Histopathological changes of fibroadenosis include fibrosis, adenosis, microcysts, and epithelial hyperplasia. ${ }^{19}$ Of these fibrosis and microcysts less seen on cytology with predominant component of epithelial cells arranged in monolayered sheets arrived to diagnose as fibroadenoma.

Nine cases diagnosed at cytologically as benign proliferative breast disease, five cases on histopathological diagnosis proved to be fibroadenoma, those had antler horn pattern and bare nuclei. In the three cases where apocrine cell clusters and cyst macrophages are seen plenty with few ductal epithelial cells, a histopathological diagnosis of fibrocystic disease is given. Remaining one case showed dual population of ductal epithelial cells and myoepithelial cells without atypia and bare nuclei in the background, diagnosed as ductal hyperplasia on histopathology

Two cases of benign phyllode tumor on histopathology showed characteristic stromal hypercellularity with occasional ductal epithelial cells in a leaf like pattern without atypia, concluded as benign phyllode tumor.

Seven cases are diagnosed as PBD with atypia on cytology. Among these atypical smears one case showed inflammatory cells along with ductal epithelial cells. On histopathological examination of this case, there is no evidence of atypia or malignancy in several sections studied. Atypia seen on cytology may be accompaniment of reactive changes due to inflammation. Remaining six cases are diagnosed as malignant on histopathology.

\section{Comparison of Newly Proposed Grading System With Histopathology}

Ten cases diagnosed as benign by Newly proposed cytology grading system. Among these nine cases showed increased gland to stromal ratio with characteristic intra-canalicular and peri-canalicular pattern on histopathological examination, concluded as fibroadenoma. Remaining one case showed fibrosis, microcysts and epithelial hyperplasia diagnosed as fibroadenosis.

Among 37 PBD without atypia cases, 29 cases showed features of fibroadenoma on histopathological examination. Three cases diagnosed as fibroadenosis. Four cases showed stromal hypercellularity in a leaf like arrangement and concluded as phyllode tumor. Sections studied in the remaining one case showed dual population of ductal epithelial cell cells and myoepithelial cells without atypia. Also seen are bare nuclei in the background, diagnosed as ductal hyperplasia.

Sections studied on five PBD with atypia cases, four cases diagnosed as malignant. One case with inflammatory 
cells admixed atypical ductal epithelial cells concluded as benign breast disease.

On histopathological examination of two malignant cases, discohesive cell clusters with pleomorphic nuclei and stromal invasion are seen. Diagnosed as malignant

\section{Comparison of Masood Grading System with Newly Proposed Grading System}

Proliferative breast disease without atypia on Masood grading system showed concordance with Newly proposed grading system. Out of 47 PBD without atypia on Masood system, 37 cases graded as PBD without atypia in newly proposed grading system. 10 cases graded as benign. This is because, few cases with ductal epithelial cells which are scored under nuclear overlapping in Masood grading system, scored as monolayered sheets in newly proposed grading system. Myoepithelial cells of moderate in number scored as many in newly proposed grading system. These parameters influenced overall score and graded low in new grading system compared with Masood grading system.

Of seven atypical cases on Masood grading system, five cases showed correlation with newly proposed grading system. Two cases graded as malignant. The reason for the over grading of the tumors by the newly proposed method appears to be the presence of mitosis, cell size and nuclear margin in the two discordant cases. Mitosis, cell size, nuclear margin and necrosis parameters used for grading by newly proposed method, whereas these are not taken into consideration in Masood method. Also cell size and nuclear margin are influential features in other studies like robinson et al and khan et al respectively. ${ }^{23,24}$

Overall $52(96.3 \%)$ cases out of 54 cases on Masood correlated with the newly proposed system. Two cases (3.7\%) graded as PBD with atypia on Masood system are graded as malignant on Newly proposed system. On histopathology these two cases confirmed as malignant. The Newly proposed grading system will help the cytologist to classify benign breast lesions into different categories as well as grade malignant breast lesions. Hence, this novel cytological grading system will help the cytologist to categorize any breast lump accordingly.

Chi-square test is used to test an association between two categorical variables. Obtained $\mathrm{p}$ value tells the significance of association. $p$ value $<0.005$ implies significant association. ${ }^{25}$ In the present study, comparing Masood with histopathology obtained pvalue is 0.000 $(<0.005)$. Newly proposed grading system compared with histopathology and p-value is $0.000(<0.005)$. This implies significant association of the two grading systems with histopathology. Comparing Masood grading system with newly proposed system p-value is $0.000 \quad(<0.005)$, showed significant association Sensitivity, Specificity, PPV, NPV are calculated and compared with previous studies showed significant results. (Table- 7).

\section{Interobserver Variability}

The level of interobserver agreement is tested by calculating cronbach's alpha. Cronbach's alpha is used as a estimate of the reliability of a psychometric test. The reliability is good if the Cronbach alpha is $>0.7$. In the present study, Cronbach alpha for Masood scores - 0.978 Cronbach alpha for New scores -0.955

\section{Summary}

The study included 54 cases. These cases are graded by Masood system and newly proposed system separately and correlated with the histopathologic findings. Finally Masood system is compared with newly proposed system. 12 cases showed discordance between Masood and newly proposed system in PBD with atypia (two cases) and PBD without atypia (ten cases) groups.

These discordant cases on histopathologic examination showed concurrence with newly proposed grading system which implies the increased diagnostic efficacy of newly proposed system.

Chi-square statistical test is done which showed a p-value $<0.005$. This implies significant association of two grading systems. Sensitivity, specificity, positive predictive value and negative predictive value for newly proposed grading system are $88.67 \%, 100 \%, 100 \%$ and $85.71 \%$ respectively.

\section{Conclusion}

A simple slide based scoring system of epithelial lesions of breast is a useful tool in the prognostication and prediction of behavior of proliferative epithelial lesions.

Our newly proposed grading system is a reliable and reproducible system, which can assist the cytologist to efficiently grade various epithelial lesions of breast, both benign and malignant like Masood grading system. Thus, this newly proposed grading system helps in prognostication.

\section{References}

1. Chokshi MH, Mehta NP. Cytological study of palpable breast lumps (407 cases) with their histological correlation. Int J Med Sci Public Health 2014;3:181-5.

2. Einstien D, Omprakash BOP, Ganapathy H and Rahman S. "Comparison of 3- Tier Cytological Grading Systems for Breast Carcinoma". ISRN Oncology 2014;1-6. doi:10.1155/2014/252103 
3. Jarwani PB, Patel DC, Patel SM, Dayal A. Fine Needle Aspiration Cytology in A Palpable Breast Lump. GCSMC J Med Sci 2013;2:12-6.

4. Bansal C, Pujani M, Sharma KL, Srivastava AN, Singh US. Grading systems in the cytological diagnosis of breast cancer: A review. J Can Res Ther 2014;10:839-45.

5. Nandini N M, Rekha T S, Manjunath G V. Evaluation of scoring system in cytological diagnosis and management of breast lesion with review of literature. Indian J Cancer 2011;48:240-5

6. Phukan JP, Sinha A, Deka JP. Cytological grading of breast carcinoma on fine needle aspirates and its relation with histological grading. South Asian J Cancer 2015;4:32-4.

7. Masood S, Frykberg ER, McLellan GL, Dee S, Bullard JB. Cytologic differentiation between proliferative and nonproliferative breast disease in mammographically guided fine-needle aspirates. Diagn Cytopathol. 1991;7:581-90.

8. Sidawy MK, Stoler MH, Frable WJF, et al. Interobserver variability in the classification of proliferative breast lesions by fine-needle aspiration: Result of the Papanicolaou Society of Cytopathology study. Diagn Cytopathol 1998;18:150-65.

9. Lester SC. The Breast. In: Kumar V, Abbas A.K, Fausto N, Aster J.C editors. Robbins and cotron pathologic basis of disease. 9th ed. Philadelphia: Saunders Elsevier; 2010. P 1044-70.

10. Ryu A, Takenaka A, Nagata S, Tomita Y. Scoring system of fine needle aspiration cytology samples for the detection of non-high-grade ductal breast carcinoma. Oncocytology Journal 2013;3:1-7.

11. Okoth C, Galukande M, Jombwe Jand Wamala D. Benign proliferative breast diseases among female patients at a sub Saharan Africa tertiary hospital: A cross sectional study. BMC Surgery 2013; 13:9.

12. Gangopadhyay M, Nijhawan R, Joshi K, and Gupta S. Cytology of "Significant" Breast Ductal Proliferations. Acta Cytol 1997;41(4):1112-20.

13. Singh P, Chaudhry M, Nauhria S, Rao D. Cytomorphological patterns of breast lesions diagnosed on fine-needle aspiration cytology in a tertiary care hospital. Int J Med Sci Public Health 2015;4(5):674-9.

14. Pandey P, Dixit A, Chandra S, Kaur S. A Comparative and Evaluative Study of Two Cytological Grading Systems in Breast Carcinoma with Histological Grading: An Important Prognostic Factor. Analytical Cellular Pathology 2014;1-6
15. Bibbo M, Wilbur DC, Comprehesive Cytopathology, 3rd ed. Philadelphia: Saunders Elsevier; 2008.p 713-50.

16. Orell SR, Sterret GF, Whitaker D. Fine needle aspiration cytology, 4th ed, Churchill Livingstone: Elsevier, 2005:165201.

17. Mendoza P, Lacambra M, Tan PH, Tse GM. Fine needle aspiration cytology of the breast: The nonmalignant categories. Pathology Research International 2011;1-8.

18. Bandyopadhyay R, Nag D, Modal SK, Mukhopadhyay S, Roy S, Sinha SK. Distinction of phylloides tumor from fibroadenoma: Cytologists' perspective. J Cytol. 2010; 27(2):59-62.

19. Corder AP, Carpenter R, Smallwood JA, Johnson CD. Fibroadenosis of the breast does not require excision biopsy. Postgrad Med J 1990;66:650-3.

20. Zoah C, Raza A, Martin SE, Pan J, Greaves TS, Cobb CJ et al. Breast FineNeedle Aspiration Samples Reported as "Proliferative Breast Lesion": Clinical Utility of the Subcategory "Proliferative Breast Lesion With Atypia". Cancer Cytopathol 2009;117:137-47.

21. Singh MK, Kumar A, Nag S. Giant fibroadenoma of breast mimicking phyllodes tumor in an adolescent girl: Case report. IOSR Journal of Dental and Medical Sciences 2014;13(12):32-4.

22. Singh SK, Kunal, Nag S. A giant juvenile fibroaddenoma of breast. IOSR Journal of Dental and Medical Sciences 2015;14(7):1-2.

23. Robinson IA, McKee G, Nicholson A, D’Arey J, Jackson PA, Cook MG, et al. Prognostic value of cytological grading of fine-needle aspirates from breast carcinomas. Lancet 1994; 343:947-9.

24. Khan N, Afroz N, Rana F, Khan MA. Role of cytologic grading in prognostication of invasive breast carcinoma. $\mathrm{J}$ Cytol 2009;26:65-8.

25. Peacock JL, Peacock PJ. Oxford handbook of medical statistics. United States:Oxford University Press; 2011.

26. Jindal U, Singh K, Kochhar A. Fine Needle Aspiration Cytology Of Breast Lumps With Histopathological Correlation: A Four Year And Eight Months Study From Rural India. The Internet Journal of Pathology 2012;13(3):1-5.

27. Choi YD, Choi YH, Lee JH, Nam JH, Juhng SW, Choi C. Analysis of fine needle aspiration cytology of the breast. Acta Cytol. 2004;48(6):801-6.

*Corresponding author:

Sai Chandana Gali, 18-1-46/N, Prashanthi Nagar, K.T. Road, Tirupathi - 517507,Chittoor, Andhra Pradesh, India,

Phone: +91 8985555244, 0877-2235366

Email: chandana.gali@gmail.com

Financial or other Competing Interests: None. 